\title{
Tüketici Davranışında Bir Fikir Lideri Olarak Influencerlar ${ }^{1}$
}

\author{
(Araştırma Makalesi)
}

Influencers as Opinion Leaders in Consumer Behaviour

Doi: 10.29023/alanyaakademik.881073

\section{Fikret YAMAN}

Doç.Dr., Afyon Kocatepe Üniversitesi, İktisadi ve İdari Bilimler Fakültesi, Uluslararası

Ticaret ve Finansman

fyaman@aku.edu.tr

ORCID No: 0000-0002-5341-6603

Bu makaleye atıfta bulunmak için: Yaman, F. (2021). "Tüketici Davranışında Bir Fikir Lideri Olarak Influencerlar”. Alanya Akademik Bakış, 5(2), Sayfa No.953-970.

Anahtar kelimeler:
Influencer,
Fikir Lideri,
Tüketici,
Tüketici Davranışı
Makale Geliş Tarihi:
15.02.2021
Kabul Tarihi:
06.04.2021

Keywords:

Influencer, Opinion Leader, Consumer, Consumer Behaviour

\begin{abstract}
ÖZET
Günümüzde rekabetin ve ürün çeşitliliğinin artması, işletmeler için; tüketici ve onun sergilediği davranışları daha da önemli hale getirmiştir. Tüketici, bu davranışlarında çeşitli kişi ve faktörlerden etkilenmektedir. Aile, arkadaş çevresi ve fikir liderleri bu etkileyicilerin başında gelmektedir. Son zamanlarda sosyal medya platformlarının kullanımının ve etkileyiciliğinin artması, tüketici davranışlarında bir fikir lideri olarak influencerları ön plana çıkarmıştır. Influencerlar; mal, hizmet ya da fikirlerle ilgili deneyimlerini tüketicilerle paylaşı onlar etkileyebilmektedirler. Çalışmada 500 kişiye kolayda örnekleme yöntemiyle online anket uygulanmış ve toplanan veriler analiz edilmiştir. Çalışmanın amacı, tüketici davranışında influencerların tüketiciler tarafindan bir fikir lideri olarak görülüp görülmediğini tespit etmektir. Çalışmada sosyal medya kullanıcısı olan tüketicilerin influencerları bir fikir lideri olarak gördükleri ve bunun tüketicilerin yaş, eğitim, cinsiyet, gelir düzeyi gibi demografik özelliklerine göre farklılaş̧ı̆̆ı sonucuna ulaşılmıştır.
\end{abstract}

\begin{abstract}
At the present time, the increasing of competition and product range make consumers and their behaviours more important for businesses. The consumer is influenced by a variety of individuals and factors, primarily family, circle of friends, and opinion leaders in his or her behaviors. Recently, the increase in the use and impressiveness of social media platforms has brought influencers to the fore as opinion leaders in consumer behavior. Influencers able to affect consumers by sharing own experiences about goods, services and ideas. In this study, online survey was conducted to 500 participants with convenience sampling method and the collected data was analyzed. The aim of the study is to determine whether influencers are seen as opinion leaders by consumers in consumer behavior. In this
\end{abstract}

\footnotetext{
${ }^{1} \mathrm{Bu}$ çalışma, Afyon Kocatepe Üniversitesi Sosyal ve Beşeri Bilimler Bilimsel Araştırma ve Yayın Etik Kurulu'nun 18.09.2020 tarih ve 2020/149 sayılı kararınca "Etik Kurul Onayı" alınarak ve katılımcılara araştırma hakkında gerekli bilgilendirmeler yapılarak tamamlanmıştır.
} 
study, it is extrapolated that consumers who are social media users consider influencers as an opinion leader and this consideration differs according to consumers demographic characteristics such as age, education, gender and income level.

\section{GÍRIŞ}

Gelişen teknoloji, insanların sosyalleşme çabaları ve mecralardaki artış hayatımıza yeni kavramların girmesine neden olmaktadır. Tüketici ihtiyaç ve isteklerinin neler olduğunu bilmek işletmeler için mal ya da hizmetlerini pazarlamak bakımından çok önemlidir. İşletmeler tutundurma faaliyetleri kapsamında tüketicilere ulaşmakta ve satın alma davranışı göstermeleri için onları teşvik etmektedirler. Bunu yaparken de son zamanlarda sosyal medyada bazı kişilerin yardımını almaktadırlar.

Sosyal medya özellikle son on yılda gencinden yaşlısına hayatımızda çok önem arz eden bir araç haline gelmiştir. Sadece arkadaşlar, akrabalar ya da işletmelerle diyaloğa geçmek için değil aynı zamanda işletmeler ve ürünleri hakkında bilgi edinmek için de sosyal medya tüketicilere farklı alternatifler sunmaktadır.

Tüketicilerin satın alma davranışlarında geçmişten günümüze birçok kişinin etkisi olmuştur. Aileler, arkadaşlar, toplumda fikir lideri olarak benimsenmiş kişiler bunlara en iyi örneklerdir. Son yıllarda influencer adı verilen fikir liderleri de tüketici davranışında önemli bir rol üstlenmektedir. Fikir lideri aynı zamanda kanaat önderi olarak da adlandırılabilir. Influencerlar son zamanlarda sosyal medya kullanıcıları için birer kanaat önderi olmuş durumdadırlar. Influencer kelimesinin Türkçe karşılığı “etkileyici” demektir. Pazarlama literatüründe bu isimle kullanıldığı için çalışmada da bu isim üzerinden hareket edilmiştir.

Influencerlar bazen işletme ile birlikte bazen de herkesten bağımsız biçimde sosyal medya üzerinden tüketicilerin davranışlarına yönelik olarak olumlu ya da olumsuz etkiler sergileyebilmektedirler.

$\mathrm{Bu}$ çalışmada da influencerların tüketici davranışı üzerinde demografik değişkenlere göre farklılık gösterip göstermediği araştırılmıştır.

\section{TÜKETICİ DAVRANIŞI}

Bireysel ya da hane halkının istek ve ihtiyaçları doğrultusunda mal, hizmet ya da fikirler satın alan ya da satın alma kapasitesinde olan gerçek kişilere tüketici adı verilir (İslamoğlu ve Altunışık, 2008:5).

Tüketici davranışı; mal ve hizmetlerin edinilmesi, değerlendirilmesi, kullanımı ve elden çıkarılmasındaki karar süreci ve fiziksel aktivitelerdir. $\mathrm{Bu}$ tanımda açıç̧a tüketici davranışında dikkat çeken şeyin sadece mal ve hizmet alımı olmadığı, sürecin mallar satın alınmadan çok önce başladığı belirtilmiştir. Tüketici davranışında, tüketicinin zihninde bir satın alma süreci başlar ve bu da görece avantaj ve dezavantajları ile tüketicinin ürün alternatifleri arasında seçim yapmasını sağlar (Khan, 2006:4).

Tüketici davranışlarında dört boyut vardır. Bunlar; kişisel özellikler, psikolojik özellikler, sosyal özellikler ve kültürel özelliklerdir (Lakshmi, 2016: 61). 
Son elli yılda tüketici davranışı, sosyal bilim araştırmacıları için önemli bir ilgi alanı olmuştur. Toplumdaki, ekonomideki ve teknolojideki değişiklikler tüketicilerin davranış biçimini etkilediği için, tüketici davranışına ilişkin literatür çeşitli ve kapsamlıdır (Peighambari v.d., 2016:1).

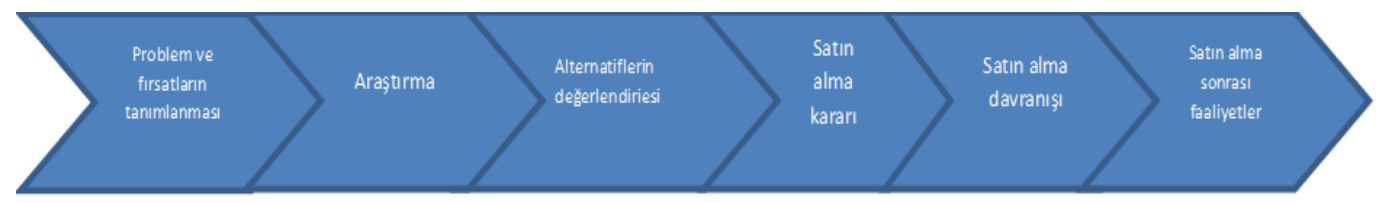

Şekil 1. Tüketici Davranışı Sürecinin Aşamaları

Kaynak: Köylüoğlu v.d., 2018: 318.

Tüketici davranış süreci altı aşamadan oluşmaktadır. İlk aşamada tüketici, problem ve fırsatları tanımlar. Yani ihtiyaç ve isteklerinin neler olduğunu belirler. İstek ve ihtiyaçlarını belirleyen tüketici daha sonra bunlar ile ilgili araştırma yapar. Araştırma sonrası alternatifleri belirleyerek satın alma kararı verir. Satın alma davranışını gerçekleştiren tüketici, satın alma sonrasında da memnuniyet ya da memnuniyetsizliğini belirleyerek davranış sürecini tamamlar. Örneğin, iş yerine ulaşımda zorluk yaşayan birey bir otomobile ihtiyacının olduğunu düşünür. Otomobil almaya karar verdikten sonra otomobillerle ilgili bir araştırma yapar. Otomobil markaları arasındaki alternatifleri belirler. Bu otomobiller arasından birini satın almaya karar verir. Karar verdiği otomobili satın alan tüketici, araca dair memnuniyet ya da memnuniyetsizliğini dile getirerek davranış sürecini bitirir.

Çoğu akademisyen ve uygulayıcı, pazarlamacının kontrolü ve etkisinin haricinde demografik, sosyal, ekonomik, kültürel, psikolojik ve diğer kişisel faktörlerin de tüketicinin satın alma kararı üzerinde büyük bir etkiye sahip olduğunu düşünmektedir (Constantinides, 2004:111).

Pazarlama ekibinin müşterilerin satın alma sürecini ve satın alma kararını etkileyen faktörleri anlaması önemlidir. Arka planda müşterileri nihai karara götürmede önemli olan birkaç faktör bulunmaktadır (Auf v.d.,2018:178). Fikir liderleri de bu faktörlerden bir tanesidir. Günümüzün fikir liderleri ise, sosyal medyadaki influencerlardır.

Tüketici davranışları; bilişsel ve davranışsal olarak iki yaklaşımı barındırır. Bilişsel olarak tüketicileri ikna etmek isteyen işletmeler, reklam başta olmak üzere tutundurma karması öğelerini kullanırlar. Bilişsel yaklaşımda tüketicilerin düşünce, tutum ve inançları önemlidir. Başarılı reklam kampanyaları ile desteklenen duruma yönelik yaklaşım ise davranışsal yaklaşımdır (Özdemir v.d., 2016:4).

Tüketici davranışlarını etkileyen içsel ve dışsal değişkenler vardır. İçsel değişkenler, öğrenme, dikkat, ilgi, güdülenme, algılama, tutum, kişilik ve yaşam tarzı iken, dişsal değişkenler ise; demografik değişkenler, kültürel değişkenler, sosyal gruplar, referans grupları ve ailedir (İslamoğlu, 2003:54).

\section{FÍKIIR LIDERI OLARAK INFLUENCERLAR}

Fikir liderliği; bir bireyin sosyal ağda etkileme yeteneğini ifade eder. Fikir liderleri, sosyal sistemler içerisindeki en etkili gruptur. Potansiyel tüketiciler bir ürün piyasaya yeni çıktığında ya da söz konusu ürüne aşina olmadıklarında, bu ürünü satın almayı yüksek risk ve 
belirsizlikle ilişkilendirirler (Nunes v.d., 2018:58). Tüketicileri bu risk ve belirsizlikten kurtaran ise fikir liderleridir.

Fikir liderleri sosyal ağlarda diğer insanlardan daha etkilidirler. Kendilerini ev politikası, moda gibi belirli bir ilgi alanında uzman olarak görürler ve bu alanda kendilerinin tavsiyeleri istenir. Fikir liderleri bu alandaki bilgilerini başkalarına aktarırlar. Başkalarına aktardıkları bilgileri de az çok bilinçli olarak değiştirebilirler (Trepte ve Scherer, 2010:119).

Tüketiciler, uzman olmayan kaynaklardan çok fikir liderlerinden tavsiye alma ve bunlardan etkilenme eğilimindedirler. Bunun nedeni; fikir liderliğinin satın alma işleminin değerlendirilme aşamasında algılanan riski azaltmasıdır. Bir fikir liderinin mesajı arayanın satın alma kararında önemli bir etkiye sahiptir (Tejavibulya ve Eiamkanchanalai, 2011:14).

Fikir liderleri, başkalarının tutum ve davranışlarını biçimsel olmayan bir biçimde etkilemektedirler. Fikir liderlerinin işlevleri şunlardır (Odabaşı ve Barış, 2007: 278);

- $\quad$ Biçimsel olmayan liderlik özelliklerine sahip olmak,

- Ürün ile ilgili olarak kişileri olumlu ya da olumsuz bir biçimde etkilemek,

- Yeniliklerin kabulünde rol oynamak,

- Yaptıkları ile taklit edilmek.

Geçmişte bireylerin, insanlar üzerinde etki uyandırabileceği mecralar sayı ve erişim açısından sınırlı idi. Önceleri tanınabilmek için tanınmış bir şirkette statü sahibi ya da medya ve dergilerde geniş çapta yayınlanmış bir kişi olmak gerekiyordu. Gelişen teknoloji ile birlikte bir bilgisayar, telefon hattı ya da kablosuz bağlantıya erişmek artık insanları etkilemede yeterli duruma geldi (Brown ve Hayes, 2008:147). Bunun sonucu olarak influencer ad1 verilen bir meslek grubu ortaya çıktı. Günümüzde sosyal medyanın hızla gelişmesi ile birlikte birçok alanda insanların davranışlarını ve fikirlerini etkileyen influencerlar vardır.

Influencer; İngilizce nüfuz kelimesinden gelmektedir. Influencer; eylemleri ve eylemleri yoluyla başkalarını etkileyen kişi demektir. Influencer'ın statüsü ve popülaritesi belirleyici rol oynamaktadır. Influencer, yetkisi ve popülerliği sayesinde başkalarının fikirlerini ve davranışlarını etkileyebilir (Jahnke, 2018:4).

İlk defa sosyolog Stanley Milgram'ın ortaya attı̆̆ı; küçük dünya fenomeni kavramı, bireylerin internet sayesinde iletişime geçmeleri ile birlikte güçlenmeye başlamıştır. Günümüzde önemi giderek artan sosyal medya; internet kullanıcılarının birbirleriyle çevrimiçi iletişim kurmalarını sağlayan, içerik paylaşımına ve kişisel yorumlara dayanan sosyal ağ siteleri olarak tanımlanabilir. Sosyal medyada temel amaç; bireyler, içerikler ve veriler arasında karşılıklı olarak etkileşim sağlamak ve bu etkileşimin bir sonucu olarak yeni iş olanakları, sosyal yapı ve teknolojik sunumlar ile dijital gelişimin sağlanmasıdır (Özdemir v.d., 2014:59).

Bireylerin deneyimlerini, etkinliklerini, fikirlerini, kullandıklarını, memnuniyet ya da memnuniyetsizliklerini paylaşmaları insanoğlunun birlikte yaşamaya başladığı andan itibaren devam eden bir süreçtir. Son yıllarda gerek internet gerekse teknolojik gelişmeler ve sosyal paylaşım mecralarındaki artışın bir sonucu olarak daha fazla içerik ve bilgi daha fazla insanla paylaşılır hale gelmiştir. Geçmişte geleneksel mecralarla birer alıcı olan bireyler, günümüzde birer yayıncı haline gelmişlerdir. Takipçi kazanmak, beğeni almak gibi nedenlerden dolayı 
insanlar artık kendilerini birer yayın organı ya da yayın yönetmeni gibi görmektedirler (Şimşek,2013:215).

Son yıllarda sosyal paylaşım siteleri, her gün milyonlarca insan tarafından ziyaret edilen ve üye olunan son derece etkili bir reklam mecrası haline gelmiştir. Farklı uygulamalara izin veren özellikleri itibariyle sosyal medya mecraları kişiler arası iletişimi güçlendirmekte ve bu sayede geniş bir kitleye ulaşmaktadır. Bu mecralar birçok amaçla kullanılmaktadır. İnsanlar ürün ve marka ile ilgili deneyimlerini, hikayelerini bu sitelerde paylaşmakta ve bu paylaşımlar aynı anda birçok kullanıcıya ulaşabilmektedir (Hacıefendioğlu, 2011:108).

Halkla ilişkilerle ilgili faaliyetlerde hedef kitleye örnek olarak özdeşlik sağlayan ve onların davranışlarına etki eden fikir liderleri; kültür, sanat, spor gibi alanlarda toplumu yönlendirebilmektedirler. Toplumu oluşturan bireylere tek tek ulaşmak yerine, toplum üzerinde etkisi olan fikir liderleri aracılığıyla harekete geçmek büyük kolaylıklar sağlamaktadır (Gültekin, 2005: 213).

Influencerlar, sosyal medya platformlarında etkili ve nitelikli takipçi kitlesi ile etkileşim içerisinde olan ve tüketicilere sunup tanıttıkları ürünün markalaşma sürecine ve tüketici satın alma davranışına destek olan reklam ajansı yönetimi çatısı altında çalışan kişi ya da gruplardır (Sarıtaş, 2018:66).

Tüketiciler, demografik özellikleri, yaşam tarzları ve kültürlerine uygun olarak farklı amaçlar için sosyal medya uygulamalarından yararlanmaktadırlar. Tüketiciler bu sosyal medya uygulamalarını ya diğer insanlarla iletişim kurabilmek ya da çeşitli markalar hakkında güvenebilecekleri yorumlar yapan kişilerle bağlantı sağlamak amacıyla kullanmaktadırlar. Markalar hakkında yorumlar yapan kişilerle bağlantı kurma amacındaki tüketiciler yüksek takip sayısı olan influencerları daha güvenilir ve fikir lideri olarak görmektedirler. İşletmeler de bu nedenle influencerlarla işbirliği yapmayı tercih etmektedirler (Canöz v.d., 2020:80).

Geleneksel fikir liderleriyle karşılaştırıldığında influencerlar sosyal medya platformları sayesinde tüketicilere daha geniş bir ulaşım imkanı sağlar ve ağızdan ağıza pazarlamada etkin uyarıcı görevini görürler (Gedik, 2020:366). Günümüzde sosyal medya sayesinde fikir liderleri influencer olarak konumlandırılmaktadır (Deniz, 2020:163).

Tablo 1. Türkiye'nin En Etkili Influencerları

\begin{tabular}{|c|c|c|}
\hline Influencer & Takipçi Sayısı & İnsanlar Üzerindeki Etki Gücü Skoru \\
\hline Danla BİLİC & 4.8 milyon & 9.90 \\
\hline Eylül ÖZTÜRK & 2.9 milyon & 9.85 \\
\hline Aykut ELMAS & 5.1 milyon & 9.85 \\
\hline Oğuzhan UĞUR & 2.5 milyon & 9.80 \\
\hline Yasemin Sakallığlu & 3.8 milyon & 9.77 \\
\hline Şeyda ERDOĞAN & 1.3 milyon & 9.73 \\
\hline Pelin AKİL & 2.4 milyon & 9.70 \\
\hline
\end{tabular}




\begin{tabular}{|c|c|c|}
\hline Duygu ÖZASLAN & 1.7 milyon & 9.70 \\
\hline Berkcan GÜVEN & 3.1 milyon & 9.68 \\
\hline Damla ALTUN & 447 bin & 9.65 \\
\hline
\end{tabular}

Kaynak: https://www.webtekno.com/influencer-ne-demek-h91000.html

Yukarıdaki tabloda yer alan sıralama ve puanlar, CreaterDen Influencer Ajansı tarafindan 2019 yılının genelini kapsayan araştırmanın sonuçlarına aittir. Puanlar, influencerların insanları ne ölçüde etkilediğini tespit eden sektörel metriklere göre hesaplanmıştır (https://www.webtekno.com/influencer-ne-demek-h91000.html) .

Tablo 1'de ülkemizdeki influencerların takipçi sayıları ve insanlar üzerindeki etki gücü skoru yer almaktadır. 2019 yılındaki bu araştırmaya göre; ülkemizde insanlar üzerinde en büyük etkiye sahip influencer, Danla Bilic’tir. Onu Eylül Öztürk ve Aykut Elmas takip etmektedir. Tabloya göre en fazla takip edilen influencer 5.1 milyon kişi ile Aykut Elmas’tır. Onu 4.8 milyon kişi ile Danla Bilic takip etmektedir.

\section{ARAŞTIRMA HAKKINDA GENEL BİLGILER ve BULGULAR}

Çalışmada veriler 2020 yılı Ekim ayında pandemi şartları göz önünde bulundurularak internet üzerinden, Google Form aracılığı ile online anket yöntemi kullanılarak toplanmıştır. Veri toplamada kullanılan anket formu 4'ü demografik soru, 2'si katılımcıların davranışlarına yönelik soru olmak üzere, tamamen katılmıyorum, katılmıyorum, fikrim yok/kararsızım, katılıyorum, tamamen katılıyorum şeklinde beşli ölçekte hazırlanmış 24 ifadeden oluşan toplam 30 sorudan oluşmaktadır. Ölçek; literatür taraması sonrasında oluşturulmuştur. Öncelikle 35 kişiden oluşan bir gruba pilot uygulama yapılmış ve anket formunda gerekli düzenlemeler yapılarak çalışmaya başlanmıştır. Araştırmanın anakütlesini Türkiye genelinde yaşayan tüketiciler oluşturmaktadır. Bu kişiler içinde kolayda örnekleme yöntemi ile Türkiye'nin farklı bölgelerinde yaşayan 500 kişiden toplanan veriler analize dahil edilmiştir. Araştırma sonuçlarını ülkemiz açısından genellemek doğru değildir. Ancak genel hakkında fikir vermesi ve bundan sonraki çalışmalara bir örnek teşkil etmesi bakımından önemlidir. Son yıllarda influencerlarla ilgili çalışmalarda artış gözlemlenmektedir. Bu çalışmada tüketicilerin farklı demografik özelliklerine göre daha çok hangi alanlarda faaliyet gösteren influencerları takip edip, onları fikir lideri olarak gördüklerinin tespit edilmesi çalışmanın özgünlüğünü ortaya koymaktadır. Araştırmada kullanılan soru formunun güvenilirliği test edilmiş ve soru formu güvenilir (Cronbach Alpha=0.81) bulunmuştur. Çalışmada tüketicilerin tutumlarını ölçmede $t$ testi ve varyans analizinden yararlanılmıştır. Çalışma için etik kurul raporu; 18.09.2020 tarih ve 2020/149 karar numarası ile Afyon Kocatepe Üniversitesi Sosyal ve Beşeri Bilimleri Bilimsel Araştırma ve Yayın Etiği Kurulu'ndan alınmıştır. Bu rapor çalışma ile birlikte gönderilmiştir.

Tablo 2. Katılımcıların Demografik Özellikleri

\begin{tabular}{|c|c|c|c|c|c|}
\hline CINSIYYTINIZ & SAYI & $\%$ & YAŞINIZ & SAYI & $\%$ \\
\hline Kadın & 335 & 67.0 & 20 yaş ve altı & 173 & 34.6 \\
\hline Erkek & 165 & 33.0 & $21-30$ yaș arası & 273 & 54.6 \\
\hline EĞİTIM DURUMUNUZ & SAYI & $\%$ & $31-40$ yaş arası & 25 & 5.0 \\
\hline
\end{tabular}




\begin{tabular}{|l|c|c|l|c|c|}
\hline İlkokul & 5 & 1.0 & $41-50$ yaş aras1 & 19 & 3.8 \\
\hline Ortaokul & 8 & 1.6 & 51-60 yaş aras1 & 10 & 2.0 \\
\hline Lise & 63 & 12.6 & GELİRİIIZ & SAYI & $\%$ \\
\hline Ön lisans & 72 & 14.4 & 2325 TL ve altı & 303 & 60.6 \\
\hline Lisans & 309 & 61.8 & $2326-4000$ TL aras1 & 107 & 21.4 \\
\hline Lisansüstü & 43 & 8.6 & $4001-6000$ TL aras1 & 58 & 11.6 \\
\hline & & & 6001 TL ve üzeri & 32 & 6.4 \\
\hline TOPLAM & 500 & 100.0 & TOPLAM & 500 & 100.0 \\
\hline
\end{tabular}

Tablo 2'de araştırmaya katılan bireylerin demografik özellikleri yer almaktadır. Cinsiyet araştırmalarda önemli bir değişkendir. Cinsiyet bireylerin tercihlerine yön vermektedir. Araştırmaya katılanların \%67'si kadın, \%33'ü ise erkektir. Araştırmalarda diğer bir önemli değişken ise yaştır. Katılımcıların \%54.6'sı 21-30 yaş aralığında, \%34.6'sı da 20 yaş ve altında yer almaktadır. Eğitim de bireylerin davranışlarında etkili olan bir başka değişkendir. Katılımcıların \%61.8'i lisans, \%14.4'ü ise ön lisans mezunudur. Bireylerin tüketim davranışlarında en önemli belirleyicilerden biri olan gelir düzeyleri de bu tür araştırmalarda etkili olan değişkenlerdendir. Araştırmanın yapıldı̆̆ı dönemdeki asgari ücret dikkate alınarak yapılan sınıflandırmalara göre katılımcıların \% 60.6's1 2325 TL ve altında gelire sahipken, \% 21.4'ü ise 2326-4000 TL arasında gelire sahiptir.

Tablo 3. Katılımcıların Takip Ettikleri Influencerların Faaliyet Gösterdikleri Alanlar

\begin{tabular}{|l|c|c|}
\hline \multicolumn{1}{|c|}{ ALAN } & SAYI & \% \\
\hline Kişisel Bakım & 147 & 29.4 \\
\hline Giyim & 120 & 24.0 \\
\hline Gida & 29 & 5.8 \\
\hline Temizlik & 15 & 3.0 \\
\hline Otomotiv & 38 & 7.6 \\
\hline Kitap/Kurtasiye & 61 & 12.2 \\
\hline Teknoloji & 73 & 14.6 \\
\hline Diğer & 17 & 3.4 \\
\hline TOPLAM & 500 & 100.0 \\
\hline
\end{tabular}

Katılımcıların hangi alandaki influencerları takip ettikleri Tablo 3'te yer almaktadır. Katılımcılar en çok \%29.4 ile kişisel bakım, \%24 ile giyim, \% 14.6 ile teknoloji alanındaki influencerları takip ettiklerini ifade etmişlerdir.

Tablo 4. Demografik özelliklere göre takip edilen influencer alanları 


\begin{tabular}{|c|c|c|c|c|c|c|c|c|c|}
\hline $\begin{array}{l}\text { DEMOGRAFİK } \\
\text { ÖZELLIKKLER }\end{array}$ & SINIFLANDIRMALAR & 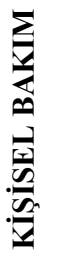 & $\sum_{\bar{J}}$ & 芯 & 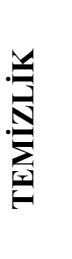 & 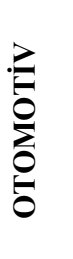 & 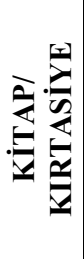 & 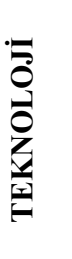 & 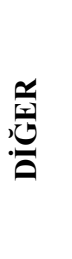 \\
\hline \multirow[b]{2}{*}{ CINSIIYETINIIZ } & Kadın & 91.1 & 78.3 & 48.2 & 93.3 & 18.4 & 70.4 & 26.0 & 58.8 \\
\hline & Erkek & 8.9 & 21.7 & 51.8 & 6.7 & 81.6 & 29.6 & 74.0 & 41.2 \\
\hline \multirow{6}{*}{$\begin{array}{l}\text { EĞİTíM } \\
\text { DURUMU }\end{array}$} & İlkokul & 2.7 & 0 & 3.4 & 0 & 0 & 0 & 0 & 0 \\
\hline & Ortaokul & 2.0 & 0 & 3.4 & 0 & 5.3 & 1.6 & 1.4 & 0 \\
\hline & Lise & 8.2 & 11.7 & 6.9 & 13.3 & 26.3 & 23.0 & 11.0 & 5.9 \\
\hline & Ön lisans & 10.9 & 16.7 & 37.9 & 0 & 15.8 & 18.0 & 8.2 & 11.8 \\
\hline & Lisans & 60.5 & 66.7 & 44.8 & 80.0 & 47.4 & 49.2 & 74.0 & 76.5 \\
\hline & Lisansüstü & 15.6 & 5.0 & 3.4 & 6.7 & 5.3 & 8.2 & 5.5 & 5.9 \\
\hline \multirow{5}{*}{ YAŞ } & 20 yaş ve altı & 34.0 & 42.5 & 37.9 & 33.3 & 34.2 & 32.8 & 23.3 & 35.2 \\
\hline & 21-30 yaş arası & 57.8 & 48.3 & 34.4 & 40 & 50.0 & 59 & 68.5 & 53 \\
\hline & 31-40 yaș arası & 5.4 & 3.3 & 6.9 & 0 & 7.8 & 4.9 & 5.4 & 5.8 \\
\hline & 41-50 yaş arası & 2.0 & 2.7 & 10.4 & 26.7 & 5.2 & 3.3 & 2.8 & 0 \\
\hline & 51-60 yaş arası & 0.8 & 3.3 & 10.4 & 0 & 2.8 & 0 & 0 & 5.8 \\
\hline \multirow{4}{*}{ GELİR } & 2325 TL ve altı & 68.7 & 60.8 & 62.1 & 53.3 & 44.7 & 65.6 & 49.3 & 58.8 \\
\hline & 2326-4000 TL arası & 13.6 & 18.3 & 10.3 & 26.7 & 34.2 & 26.2 & 34.2 & 23.5 \\
\hline & 4001-6000 TL arası & 10.9 & 16.7 & 6.9 & 6.7 & 13.2 & 6.6 & 11.0 & 11.8 \\
\hline & 6001 TL ve üzeri & 6.8 & 4.2 & 20.7 & 13.3 & 7.9 & 1.6 & 5.5 & 5.9 \\
\hline
\end{tabular}

Tablo 4'te araştırmaya katılanların Tablo 3 'te takip ettikleri influencer alanlarının demografik özelliklerine göre ayrıntıları yer almaktadır. Influencerların alanlarına göre araştırmanın bulguları şu şekildedir:

\section{Kişisel bakım;}

Katılımcıların \%29.4'ü takip etmektedir. Kişisel bakım influencerlarını takip edenlerin \%91.1'i kadın, \%8.9'u erkektir. Eğitim düzeyleri açısından kişisel bakım alanındaki influencerları takip edenlerin \%60.5'i lisans, \%15.6's1 lisansüstü, \%10.9'u ön lisans, \%8.2'si lise, \%2.7'si ilkokul, \%2'si ise ortaokul mezunudur. Kişisel bakım alanındaki influencerları takip edenlerin \%57.8'i 21-30 yaş arası, \%34'ü 20 yaş ve altı, \%5.4'ü 31-40 yaş arası, 41-50 yaş aras $1 \% 2$ ve 51-60 yaş arasında olanlar ise 0.8 'dir. Kişisel bakım alanındaki influencerları takip edenlerin gelir düzeyi incelendiğinde ise; \%68.7'sinin 2325 TL ve altındadır. \%13.6's1 2326-4000 TL aras1, \%10.9'u 4001-6000 TL aras1, \%6.8'i ise 6001 TL ve üzeri gelire 
sahiptir. Kişisel bakım alanındaki influencerları daha çok takip edenler eğitim düzeyi yüksek, gelir düzeyi düşük, genç yaştaki sosyal medya kullanıcısı kadın tüketicilerdir.

\section{Giyim;}

Katılımcıların \%24’ü takip etmektedir. Giyim influencerlarını takip edenlerin \%78.3’ü kadın, \%21.7'si ise erkektir. Eğitim durumu açısından giyim influencerlarını takip edenlerin \%66,7'si lisans, \%16.7'si ön lisans, \%11.7'si lise, \%5'i lisansüstü eğitim düzeyindedir. İlkokul ve ortaokul mezunları giyim sektöründeki influencerları takip etmemektedirler. Takipçilerin \%48.3'ü 21-30 yaş arası, \%42.5'i 20 yaş ve altı, \%2.7'si 41-50 yaş arasındadır. 31-40 yaş arası ve 51-60 yaş arasındaki takipçiler ise \%3.3'tür. 2325 TL ve altında gelir elde edenlerin \%60.8'i, 2326-4000 TL arasında gelir elde edenlerin \%18.3'ü, 4001-6000 TL aras1 gelir elde edenlerin 16.7'si ve 6001 TL ve üzerinde gelir elde edenlerin \%4.2'si giyim sektöründeki influencerları takip etmektedirler. Giyim alanındaki influencerları daha çok eğitim düzeyi yüksek, gelir düzeyi düşük, sosyal medya kullanıcısı genç kadın tüketiciler takip etmektedirler.

\section{Gida;}

Katılımcıların \%5.8'i takip etmektedir. Gıda influencerlarını takip edenlerin \%48.2'si kadın, $\% 51.8$ 'i ise erkektir. Eğitim durumuna göre gıda influencerlarını takip edenler incelendiğinde takipçilerin \%44.8'i lisans, \%37.9'u ön lisans, \%6.9'u lise mezunudur. İlkokul, ortaokul ve lisansüstü eğitim düzeyindekilerin gıda influencerlarını takip etme oranı her biri için $\% 3.4$ 'tür. Gıda influencerlarını 20 yaş ve altındakilerin takibi \%37.9, 21-30 yaş arasındakiler $\% 34.4,31-40$ yaş arası \%6.9'dur. 41-50 yaş arasındakiler ve 51-60 yaş arasındakilerin her biri için gıda influencerlarını takip etme oranı \%10.4'tür. $2325 \mathrm{TL}$ ve altındaki gelir düzeyinde olan katılımcıların \%62.1'i gıda influencerlarını takip etmektedirler. Gelir düzeyine göre 6001 TL ve üzerinde gelir elde edenler \%20.7, 2326-4000 TL arasında gelir elde edenler \%10.3, 4001-6000 TL arasında gelir elde edenlerin \%6.9'u gıda influencerlarını takip ettiklerini ifade etmişlerdir. Gıda alanındaki influencerları daha çok gelir düzeyi düşük, eğitim düzeyi yüksek, sosyal medya kullanıcısı genç erkek tüketiciler takip etmektedirler.

\section{Temizlik;}

Katılımcıların \%3'ü takip etmektedir. Temizlik influencerlarını takip edenlerin \%93.3'ü kadın, \%6.7'si erkektir. Temizlik sektöründeki influencerları takip edenlerin \% 80'i lisans, $\% 13.3$ 'ü lise eğitim düzeyindedirler. Temizlik sektöründeki influencerları takip eden lisansüstü eğitim düzeyindekiler ise \%6.7'dir. İlkokul, ortaokul ve ön lisans mezunları temizlik sektöründeki influencerları takip etmediklerini ifade etmişlerdir. 21-30 yaş arasındaki katılımcıların \%40'ı temizlik sektöründeki influencerları takip ettiklerini ifade etmişlerdir. Temizlik sektöründeki influencerları takip eden 20 yaş ve altındakiler \%33.3'tür. Temizlik sektöründeki influencerları takip edenlerin \%26.7'si 41-50 yaş aralığındadır. 31-40 yaş arası ve 51-60 yaş arasındaki katılımcılardan temizlik sektöründeki influencerları takip eden yoktur. Temizlik sektöründeki influencerları takip edenlerin \%53.3'ü 2325 TL ve altında gelir elde ettiklerini ifade etmişlerdir. Takipçilerin \%26.7'si 2326-4000 TL arası gelir elde edenlerdir. $6001 \mathrm{TL}$ ve üzeri gelir elde edenlerin \%13.3'ü temizlik sektöründeki influencerları takip etmektedirler. Temizlik sektöründeki influencerları takip edenlerin \%6.7'si ise 40016000 TL arasında gelir elde etmektedirler. Temizlik sektöründeki influencerları daha çok takip edenler eğitim düzeyi yüksek, gelir düzeyi düşük, sosyal medya kullanıcısı olan genç kadın tüketicilerdir. 


\section{Otomotiv;}

Katılımcıların \%7.6'sı takip etmektedir. Otomotiv sektöründeki influencerları takip edenlerin \%81.6'sı erkek, \%18.4'ü ise kadındır. Otomotiv sektöründeki influencerları takip edenlerin \%47.4'ü lisans, \%26.3'ü lise, \%15.8'i ön lisans eğitim düzeyindedirler. Ortaokul ve lisansüstü mezuniyet düzeyinde olanların her biri için \%5.3'ü otomotiv sektöründeki influencerları takip etmektedirler. İlkokul mezunu katılımcılardan otomotiv sektöründeki influencerları takip eden bulunmamaktadır. Otomotiv sektöründeki influencerları takip edenlerin \%50'si 21-30 yaş aralığında yer almaktadır. Katılımcılardan 20 yaş ve altındakiler \%34.2 ile otomotive sektöründeki influencerları takip eden yaş kategorisinde ikinci sırada yer almaktadır. Otomotiv sektöründeki influencerları takip edenlerin \%7.8'i 31-40 yaş arası, \%5.2'si 41-50 yaş arası ve \%2.8'i ise 51-60 yaş aralığında yer almaktadır. Otomotiv sektöründeki influencerları takip edenlerin \%44.7'si 2325 TL ve altında gelire sahip iken, \%34.2'si 2326-4000 TL aras1, \%13.2'si 4001-6000 TL aras1 gelire sahiptirler. 6001 TL ve üzerindekilerin \%7.9' u otomotiv sektöründeki influencerları takip ettiklerini ifade etmişlerdir. Otomotiv sektöründeki influencerları daha çok eğitim düzeyi yüksek, gelir düzeyi düşük genç erkekler takip etmektedir.

\section{Kitap/kırtasiye;}

Katılımcıların \%12.2'si takip etmektedir. Kitap/kırtasiye sektöründeki influencerları takip edenlerin \%70.4'ü kadın, \%29.6'sı ise erkektir. Eğitim durumları incelendiğinde takipçilerin \%49.2'si lisans, \%23'ü lise, \%18'i ön lisans, \%8.2'si lisansüstü, \%1.6'1 ortaokul mezunudur. Kitap/kırtasiye alanındaki influencerları ilkokul mezunu katılımcılar takip etmediklerini ifade etmişlerdir. Kitap/kırtasiye alanındaki influencerları takip edenlerin \%59'u 21-30 yaş aralığında, \%32.8'i 20 yaş ve altında, \%4.9'u 31-40 yaş aralığında, \%3.3'ü 41-50 yaş aralığında yer almaktadır. 51-60 yaş arasında, kitap/kırtasiye alanındaki influencerları takip eden bulunmamaktadır. Kitap/kırtasiye sektöründeki influencerları takip edenlerin \%65.6's1 2325 TL ve altında gelire sahip olanlardır. \%26.2'si 2326-4000 TL gelir aralığında olanlardır. 4001-6000 TL arasında gelir elde eden kitap/kırtasiye influencerlarını takip edenler \%6.6'dır. Kitap/kırtasiye influencerlarını takip edenlerin \%1.6'sı ise 6001 TL ve üzerinde gelir elde eden katılımcılardır. Kitap/kırtasiye alanındaki influencerları takip eden eğitim düzeyi yüksek, genç, gelir düzeyi düşük olan sosyal medya kullanıcısı kadın tüketicilerdir.

\section{Teknoloji;}

Katılımcıların \%14.6's1 takip etmektedir. Teknoloji sektöründeki influencerları takip edenlerin \%74'ü erkek, \%26'sı erkektir. Lisans eğitim düzeyinde teknoloji alanındaki influencerları takip edenler \%74'tür. Takipçilerin \%11'i lise, \%8.2'si ön lisans, \%5.5'i lisansüstü, \%1.4'ü ortaokul mezunudur. İlkokul mezunları teknoloji alanındaki influencerları takip etmemektedirler. Teknoloji sektöründeki influencerları takip edenlerin \%68.5'i 21-30 yaş aralığında, \%23.3'ü 20 yaş ve altında, \%5.4'ü 31-40 yaş aralığında, \% 2.8'i 41-50 yaş aralığında yer almaktadır. 51-60 yaş aralığındaki katılımcılar teknoloji alanındaki influencerları takip etmediklerini ifade etmişlerdir. Teknoloji sektöründeki influencerları takip edenlerin \%49.3'ü 2325 TL ve altında gelir düzeyinde olanlardır. Takipçilerin \%34.2'si, 2326-4000 TL aralığında, \%11'i 4001-6000 TL aralığında, \%5.5'i de 6001 TL ve üzerinde gelir elde ettiklerini ifade etmişlerdir. Teknoloji alanındaki influencerları daha çok gelir düzeyi düşük, eğitim düzeyi yüksek genç yaştaki erkek sosyal medya kullanıcısı tüketiciler takip etmektedirler. 


\section{Diğer;}

Diğer seçeneğini seçen genel katılımcılar içerisinde \%3.4 olan katılımcılar; hobi, kişisel gelişim, eğitim, spor gibi alanlardaki influencerları takip ettiklerini ifade etmişlerdir. Diğer seçeneğini tercih eden takipçilerin \%58.8'i kadın, \%41.2'si erkektir. Diğer seçeneğini eğitim düzeylerine göre tercih edenlerin $\% 76.5$ 'i lisans, \%11.8'i ön lisans, \%5.9'u lise, \%5.9'u lisansüstü eğitim düzeyindedirler. İlkokul ve ortaokul mezunları diğer seçeneğini tercih etmemişlerdir. Diğer seçeneğini tercih edenlerin \%53'ü 21-30 yaş arasında, \%35.2'si 20 yaş ve altında, \%5.8'i 31-40 yaş arası, \%5.8'i 51-60 yaş arasında yer almaktadır. 41-50 yaş aralığındaki katılımcılar diğer seçeneğini tercih etmemişlerdir. Diğer seçeneğini tercih eden takipçilerin \%58.8'i 2325 TL ve altında gelir elde ettiklerini, \%23.5'i 2326-4000 TL, \%11.8'i 4001-6000 TL arasında, \%5.9'u da 6001 TL ve üzeri gelir elde ettiklerini ifade etmişlerdir. Diğer alanlardaki influencerları takip edenler sosyal medya kullanıcısı eğitim düzeyi yüksek, genç, gelir düzeyi düşük kadın tüketicilerdir.

Tablo 5. Katılımcıların Takip Ettikleri Influencer Sayısı

\begin{tabular}{|l|c|c|}
\hline TAKİ SAYISI & SAYI & $\%$ \\
\hline 1 & 101 & 20.2 \\
\hline 2-4 ARASI & 209 & 41.8 \\
\hline 5-7 ARASI & 92 & 18.4 \\
\hline 8-10 ARASI & 37 & 7.4 \\
\hline 10'DAN FAZLA & 61 & 12.2 \\
\hline TOPLAM & 500 & 100.0 \\
\hline
\end{tabular}

Katılımcılara takip ettikleri influencer sayısı sorulmuş ve Tablo 5'teki sonuçlara ulaşılmıştır. Katılımciların \%41.8'i 2-4 arasında influencer takip ettiklerini, \%20.2'si ise en az 1 influencer takip ettiklerini belirtmişlerdir. Tablo 5'e göre katılımcıların \%79.8'i 2 ve daha fazla sayıda influencerı takip etmektedirler. Bu oran sosyal medya alanındaki influencerların ne kadar önemli olduğunun bir göstergesidir.

Tablo 6. Demografik Özelliklere Göre Takip Edilen Influencer Sayıları

\begin{tabular}{|c|c|c|c|c|c|c|}
\hline $\begin{array}{l}\text { DEMOGRAFIK } \\
\text { ÖZELLIKKLER }\end{array}$ & SINIFLANDIRMALAR & 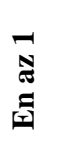 & 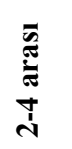 & \begin{tabular}{l}
$\overline{5}$ \\
\multirow{\pi}{\pi}{} \\
$i$ \\
in
\end{tabular} & $\begin{array}{l}\overline{\tilde{a}} \\
\stackrel{\vec{J}}{\sigma} \\
\stackrel{\sigma}{\sigma}\end{array}$ & 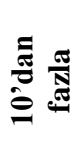 \\
\hline \multirow[b]{2}{*}{ CINSIYYETINIZZ } & Kadın & 20.6 & 40.9 & 16.1 & 9.0 & 13.4 \\
\hline & Erkek & 19.4 & 43.6 & 23.0 & 4.2 & 9.7 \\
\hline \multirow{7}{*}{ EĞİTIM DURUMU } & İlkokul & 20.0 & 40.0 & 40.0 & 0.0 & 0.0 \\
\hline & Ortaokul & 25.0 & 12.5 & 12.5 & 25.0 & 25.0 \\
\hline & Lise & 15.9 & 34.9 & 23.8 & 4.8 & 20.6 \\
\hline & Ön lisans & 25.0 & 41.7 & 16.7 & 4.2 & 12.5 \\
\hline & Lisans & 20.4 & 42.7 & 16.5 & 9.4 & 11.0 \\
\hline & Lisansüstü & 16.3 & 51.2 & 25.6 & 0.0 & 7.0 \\
\hline & 20 yaş ve altı & 20.2 & 41.8 & 18.4 & 7.4 & 12.2 \\
\hline
\end{tabular}




\begin{tabular}{|c|l|c|c|c|c|c|}
\hline \multirow{4}{*}{ YAŞ } & 21-30 yaş arası & 18.7 & 44.3 & 22.3 & 4.8 & 9.9 \\
\cline { 2 - 7 } & 31-40 yaş arası & 8.0 & 40.0 & 4.0 & 12.0 & 36.0 \\
\cline { 2 - 7 } & 41-50 yaş arası & 31.6 & 42.1 & 5.3 & 10.5 & 10.5 \\
\cline { 2 - 7 } & 51-60 yaş arası & 20.0 & 50.0 & 20.0 & 0.0 & 10.0 \\
\hline \multirow{5}{*}{ GELİR } & 2325 TL ve altı & 25.4 & 39.6 & 15.2 & 6.9 & 12.9 \\
\cline { 2 - 7 } & 2326-4000 TL arası & 11.2 & 48.6 & 27.1 & 6.5 & 6.5 \\
\cline { 2 - 7 } & 4001-6000 TL arası & 17.2 & 37.9 & 19.0 & 12.1 & 13.8 \\
\cline { 2 - 7 } & 6001 TL ve üzeri & 6.3 & 46.9 & 18.8 & 6.3 & 21.9 \\
\hline \multicolumn{7}{|c|}{} \\
\cline { 2 - 6 }
\end{tabular}

Tablo 6'da Tablo 2'deki demografik özelliklere göre takip edilen influencer sayıları yer almaktadır. Örneğin Tablo 2'deki cinsiyet değişkenine göre kadınların \%67'sinin \%100, erkeklerin \%33'ünün \%100 üzerinden değerlendirilmesi tablo 6'da istatistiki olarak yorumlanmıştır. Diğer değişkenler için de aynı durum söz konusudur. En az 1 influencer takip ederim tercihini seçen katılımcılardan en fazla 41-50 yaş arasındaki katılımcılardır. 41-50 yaş aralığında en az linfluencer takip eden katılımcılar \%31.6'dır. 2-4 arası influencer takip eden katılımciların \%51.2'si lisansüstü, \%50'si 51-60 yaş arası, \%46.9'u 6001 TL ve üzeri gelir elde edenlerdir. 5-7 arasinda influencer takip eden katılımciların \%40'1 ilkokul mezunu, $\% 27.1$ 'i 2326-4000 TL arası geliri olan katılımcilardır. 8-10 arası influencer takip eden katılımcilardan \%25'i ortaokul mezunu, \%12.1'i 4001-6000 TL aras1 gelire sahip olanlardır. 10'dan fazla influencer takip edenlerin \%36'sı 31-40 yaş aralığında, \%25'i ortaokul mezunudur. Kadınların \%40.9'u, erkeklerin \%43.6'sı 2-4 arası influencer takip ettiklerini belirtmişlerdir. İlkokul mezunlarının \%40'1 2-4, \%40'1 5-7 arası, ortaokul mezunlarının \%25'i en az 1, \%25'i 8-10 arası, \%25'i de 10 'dan fazla influencer takip ettiklerini belirtmişlerdir. Lise mezunlarının 34.9'u, ön lisans mezunlarının \%41.7'si, lisans mezunlarının \%42.7'si, lisansüstü mezunlarının \%51.2'si 2-4 arası influencer takip ettiklerini ifade etmişlerdir. Yaş değişkenine göre de en fazla 2-4 arası influencer takip edilmektedir. 20 yaş ve altındakilerin $\% 41.8$ 'i, 21-30 yaş arasındakilerin \%44.3'ü, 31-40 yaş aralığındakilerin \%40'ı, 41-50 yaş aralığındakilerin \%42.1'i, 51-60 yaş aralığındakilerin \%50'si 2-4 arası influencer takip etmektedirler. Gelir değişkeni dikkate alındığında yine en fazla 2-4 arası influencer takip edildiği dikkat çekmektedir. $2325 \mathrm{TL}$ ve altında gelire sahip olanların \%39.6's1, 2326-4000 TL arasında gelire sahip olanların \%48.6's1, 4001-6000 TL aras1 gelire sahip olanların $\% 37.9$ 'u, 6001 TL ve üzeri gelire sahip olanların \%46.9'u 2-4 arası influencer takip ettiklerini ifade etmişlerdir.

Çalışmada cinsiyet ve anketi oluşturan ifadeler arasında anlamlı bir farkın olup olmadığını tespit etmek amacıyla t-testinden yararlanılmıştır.

Tablo 7. Cinsiyete Göre Anlamlı Farklar

\begin{tabular}{|l|c|c|c|c|c|c|}
\hline \multicolumn{1}{|c|}{ İfadeler } & Cinsiyet & $\mathbf{N}$ & Ortalama & Std.sapma & F & p \\
\hline \multirow{2}{*}{$\begin{array}{l}\text { Yanlış yönlendiren } \\
\text { influencerlar hakkında } \\
\text { olumsuz yorumlar }\end{array}$} & Kadın & 335 & 3.275 & 1.2220 & & \multirow{2}{*}{0.000} \\
\cline { 2 - 6 } & Erkek & 165 & 3.721 & 1.2376 & 0.005 & \\
\hline
\end{tabular}

964 


\begin{tabular}{|c|c|c|c|c|c|c|}
\hline yaparım. & & & & & & \\
\hline \multirow{2}{*}{$\begin{array}{l}\text { Influencerların yaptıkları } \\
\text { çekilişlerin doğru olduğunu } \\
\text { düşünmüyorum. }\end{array}$} & Kadın & 335 & 3.084 & 1.2688 & \multirow{2}{*}{0.050} & \multirow{2}{*}{0.008} \\
\hline & Erkek & 165 & 3.400 & 1.2337 & & \\
\hline \multirow{2}{*}{$\begin{array}{l}\text { Ürünle ilgili sorularıma } \\
\text { cevap vermeyen } \\
\text { ınfluencerları takip } \\
\text { etmeyi bırakırım. }\end{array}$} & Kadın & 335 & 2.946 & 1.2345 & \multirow{2}{*}{6.577} & \multirow{2}{*}{0.000} \\
\hline & Erkek & 165 & 3.430 & 1.3308 & & \\
\hline \multirow{2}{*}{$\begin{array}{l}\text { Ürüne ihtiyacım olmasa } \\
\text { da influencerın anlatımı } \\
\text { sonrası satın alırım. }\end{array}$} & Kadın & 335 & 1.857 & .9866 & \multirow{2}{*}{29.364} & \multirow{2}{*}{0.001} \\
\hline & Erkek & 165 & 2.194 & 1.2826 & & \\
\hline
\end{tabular}

Tablo 7'de yapılan t-testi sonucunda ifadeler ve cinsiyet arasında anlamlı bulunan farklar yer almaktadır. Erkekler kadınlara göre yanlış yönlendiren influencerlar hakkında daha çok olumsuz yorum yapmakta, influencerların yaptıkları çekilişklerin doğru olmadığını düşünmekte, ürünle ilgili sorularına cevap vermeyen influencerları takip etmeyi bırakmakta ve ürüne ihtiyacı olmasa da influencerların anlatımı sonrası ürünü satın almaktadırlar.

Çalışmada yaş, eğitim ve gelir düzeyi ile anketi oluşturan ifadeler arasında anlamlı bir farkın olup olmadığını tespit etmek amacıyla varyans analizinden (one way anova) yararlanılmıştır.

Tablo 8. Yaș ve İfadeler Arasındaki Anlamlı Farklar

\begin{tabular}{|c|c|c|c|c|c|c|}
\hline İFADELER & YASS & $\begin{array}{c}\text { Sum of } \\
\text { Squares }\end{array}$ & df & $\begin{array}{c}\text { Mean } \\
\text { Square }\end{array}$ & $\mathbf{F}$ & Sig. \\
\hline \multirow{2}{*}{$\begin{array}{lr}\text { Influencerlar } & \text { ticari } \\
\text { düşündükleri } & \text { için } \\
\text { inandırıcı değillerdir. }\end{array}$} & Between Groups & 15.773 & 4 & 3.943 & \multirow{2}{*}{3.114} & \multirow{2}{*}{.015} \\
\hline & Within Groups & 626.779 & 495 & 1.266 & & \\
\hline \multirow{2}{*}{ 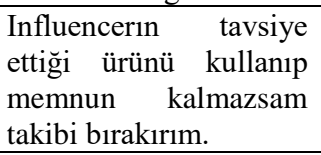 } & Between Groups & 15.415 & 4 & 3.854 & \multirow[t]{2}{*}{2.567} & \multirow[t]{2}{*}{.037} \\
\hline & Within Groups & 743.167 & 495 & 1.501 & & \\
\hline \multirow{2}{*}{$\begin{array}{l}\text { Sadece ülkemizdeki } \\
\text { 1nfluencerları değil } \\
\text { diğer ülkelerdekileri de } \\
\text { takip ediyorum. }\end{array}$} & Between Groups & 28.360 & 4 & 7.090 & \multirow{2}{*}{4.026} & \multirow{2}{*}{.003} \\
\hline & Within Groups & 871.758 & 495 & 1.761 & & \\
\hline \multirow{2}{*}{\begin{tabular}{ll}
\multicolumn{2}{l}{ Influencerların } \\
yaptıkları & çekilişlerin \\
doğru & olduğunu \\
düşünmüyorum.
\end{tabular}} & Between Groups & 22.475 & 4 & 5.619 & \multirow{2}{*}{3.585} & \multirow{2}{*}{.007} \\
\hline & Within Groups & 775.853 & 495 & 1.567 & & \\
\hline \multirow{2}{*}{$\begin{array}{l}\text { Ürünle ilgili sorularıma } \\
\text { cevap r vermeyen } \\
\text { influencerları takip } \\
\text { etmeyi bırakırım. }\end{array}$} & Between Groups & 18.084 & 4 & 4.521 & \multirow[t]{2}{*}{2.772} & \multirow[t]{2}{*}{.027} \\
\hline & Within Groups & 807.298 & 495 & 1.631 & & \\
\hline
\end{tabular}


Tablo 8'de yaş değişkeni ve ifadeler arasında yapılan varyans analizi sonucunda anlamlı farklılıklar bulunmuştur. 21-30 yaş arasındakiler 51-60 yaş arasındakilere göre daha çok ınfluencerları ticari düşündükleri için inandırıcı bulmamaktadırlar. Yine 21-30 yaş arasındakiler 51-60 yaş arasındakilere göre daha çok influencerların tavsiye ettiği ürünü kullanıp memnun kalmazlarsa takibi bırakacaklarını belirtmişlerdir. 20 yaş ve altındakiler 4150 yaş aralığındakilere göre daha çok sadece ülkemizdeki değil diğer ülkelerdeki influencerları da takip etmektedirler. 21-30 yaş arasındakiler 31-40 yaş arasındakilere göre daha çok influencerların yaptıkları çekilişlerin doğru olmadığını düşünmektedirler. 41-50 yaş aralığındaki katılımcılar 51-60 yaş arasındaki katılımcılara göre daha çok ürünle ilgili sorularına cevap vermeyen influencerları takip etmeyi bıraktıklarını ifade etmişlerdir.

Tablo 9. Eğitim ve İfadeler Arasındaki Anlamlı Farklar

\begin{tabular}{|c|c|c|c|c|c|c|}
\hline İFADELER & EĞİTİM & $\begin{array}{c}\text { Sum of } \\
\text { Squares }\end{array}$ & df & $\begin{array}{c}\text { Mean } \\
\text { Square }\end{array}$ & $\mathbf{F}$ & Sig. \\
\hline \multirow{2}{*}{$\begin{array}{l}\text { Influencerların } \\
\text { söyledikleri her zaman } \\
\text { doğrudur. }\end{array}$} & Between Groups & 22.857 & 5 & 4.571 & \multirow{2}{*}{4.024} & \multirow{2}{*}{.001} \\
\hline & Within Groups & 561.165 & 494 & 1.136 & & \\
\hline \multirow{2}{*}{$\begin{array}{l}\text { Influencerların tanıttıkları } \\
\text { ürünü mutlaka satın } \\
\text { alırım. }\end{array}$} & Between Groups & 14.765 & 5 & 2.953 & \multirow{2}{*}{2.779} & \multirow{2}{*}{.017} \\
\hline & Within Groups & 524.937 & 494 & 1.063 & & \\
\hline \multirow{2}{*}{$\begin{array}{l}\text { Influencerlar ticari } \\
\text { düşündükleri için } \\
\text { inandırıcı değillerdir. }\end{array}$} & Between Groups & 24.353 & 5 & 4.871 & \multirow{2}{*}{3.892} & \multirow{2}{*}{.002} \\
\hline & Within Groups & 618.199 & 494 & 1.251 & & \\
\hline \multirow{2}{*}{$\begin{array}{l}\text { Influencerın tavsiye ettiği } \\
\text { ürünü kullanıp memnun } \\
\text { kalmazsam takibi } \\
\text { bırakırım. }\end{array}$} & Between Groups & 25.441 & 5 & 5.088 & \multirow{2}{*}{3.428} & \multirow{2}{*}{.005} \\
\hline & Within Groups & 733.141 & 494 & 1.484 & & \\
\hline \multirow{2}{*}{$\begin{array}{l}\text { Daha önce kullanıp } \\
\text { memnun kalmadığım } \\
\text { ürünü ınfluencerın } \\
\text { tavsiyesi üzerine tekrar } \\
\text { alıp kullanırım. }\end{array}$} & Between Groups & 33.058 & 5 & 6.612 & \multirow{2}{*}{4.570} & \multirow{2}{*}{.000} \\
\hline & Within Groups & 714.692 & 494 & 1.447 & & \\
\hline \multirow{2}{*}{$\begin{array}{l}\text { Influencerın tavsiye ettiği } \\
\text { ürünü satın alamazsam } \\
\text { mutsuz olurum. }\end{array}$} & Between Groups & 14.955 & 5 & 2.991 & \multirow{2}{*}{2.616} & \multirow{2}{*}{.024} \\
\hline & Within Groups & 564.907 & 494 & 1.144 & & \\
\hline \multirow[t]{2}{*}{$\begin{array}{l}\text { Influencerlar1 samimi } \\
\text { buluyorum }\end{array}$} & Between Groups & 12.739 & 5 & 2.548 & \multirow{2}{*}{2.264} & \multirow{2}{*}{.047} \\
\hline & Within Groups & 556.053 & 494 & 1.126 & & \\
\hline \multirow[t]{2}{*}{$\begin{array}{l}\text { Influencerlar ürünleri } \\
\text { abartmaktadırlar. }\end{array}$} & Between Groups & 55.463 & 5 & 11.093 & \multirow[t]{2}{*}{9.690} & \multirow[t]{2}{*}{.000} \\
\hline & Within Groups & 565.529 & 494 & 1.145 & & \\
\hline \multirow{2}{*}{$\begin{array}{l}\text { Bazı markaları } \\
\text { influencerlar aracılığıyla } \\
\text { duydum. }\end{array}$} & Between Groups & 17.387 & 5 & 3.477 & \multirow{2}{*}{2.863} & \multirow{2}{*}{.015} \\
\hline & Within Groups & 600.045 & 494 & 1.215 & & \\
\hline \multirow{2}{*}{$\begin{array}{l}\text { Yanlış yönlendiren } \\
\text { influencerlar hakkında } \\
\text { olumsuz yorumlar } \\
\text { yaparım. }\end{array}$} & Between Groups & 29.414 & 5 & 5.883 & \multirow{2}{*}{3.914} & \multirow{2}{*}{.002} \\
\hline & Within Groups & 742.544 & 494 & 1.503 & & \\
\hline Ürünle ilgili sorularıma & Between Groups & 36.563 & 5 & 7.313 & & \\
\hline
\end{tabular}


ALANYA AKADEMIKK BAKIŞ DERGİSİ 5/2 (2021)

\begin{tabular}{|c|c|c|c|c|c|c|}
\hline $\begin{array}{l}\text { cevap vermeyen } \\
\text { influencerları takip } \\
\text { etmeyi bırakırım. }\end{array}$ & Within Groups & 788.819 & 494 & 1.597 & 4.580 & .000 \\
\hline \multirow{2}{*}{$\begin{array}{l}\text { İcinde sağlığa zararlı } \\
\text { madde bulunan ürünü } \\
\text { nffluencerlar tavsiye etse } \\
\text { de kullanmam. }\end{array}$} & Between Groups & 53.347 & 5 & 10.669 & \multirow{2}{*}{7.310} & \multirow{2}{*}{.000} \\
\hline & Within Groups & 721.075 & 494 & 1.460 & & \\
\hline \multirow{2}{*}{$\begin{array}{l}\text { Çoğu zaman influencerlar } \\
\text { tercihlerimin } \\
\text { değişmesinde etkili } \\
\text { olmuşlardır. }\end{array}$} & Between Groups & 17.026 & 5 & 3.405 & \multirow{2}{*}{2.593} & \multirow{2}{*}{.025} \\
\hline & Within Groups & 648.726 & 494 & 1.313 & & \\
\hline
\end{tabular}

Tablo 9'da eğitim durumu değişkeni ile ifadeler arasındaki anlamlı farklar yer almaktadır. Demografik değişkenler ve ifadeler arasında varyans analizi sonucunda en fazla anlamlı fark eğitim durumu ve ifadelerin analizinde ortaya çıkmıştır. Ortaokul mezunları lisansüstü mezunlarına göre daha çok influencerların söylediklerinin her zaman doğru olduğunu düşünmektedirler. Ortaokul mezunları lisansüstü mezunlarına göre daha çok influencerların tanıttıkları ürünü mutlaka satın almaktadırlar. Ortaokul mezunları lisansüstü mezunlarına göre daha çok influencerları ticari düşündükleri için inandırıcı bulmamaktadırlar. Ön lisans mezunları ilkokul mezunlarına göre daha çok influencerların tavsiye ettiği ürünü kullanıp memnun kalmazsam takibi bırakmaktadırlar. Ortaokul mezunları lisansüstü mezunlarına göre daha çok daha önce kullanıp memnun kalmadığı ürünü influencerın tavsiyesi üzerine tekrar alıp kullanmaktadırlar. İlkokul mezunları lisans mezunlarına göre daha çok influencerın tavsiye ettiği ürünü satın almazsa mutsuz olmaktadırlar. İlkokul mezunları lisans mezunlarına göre daha çok influencerları samimi bulmaktadırlar. Lise mezunları ortaokul mezunlarına göre daha çok influencerların ürünleri abarttıklarını düşünmektedirler. Ön lisans mezunları ilkokul mezunlarına göre daha çok bazı markaları influencerlar aracılığıyla duyduklarını belirtmişlerdir. Lisansüstü mezunlar ilkokul mezunlarına göre daha çok yanlış yönlendiren influencerlar hakkında olumsuz yorum yapmaktadırlar. Lise mezunları ilkokul mezunlarına göre daha çok ürünle ilgili sorularına cevap vermeyen influencerları takip etmeyi bırakmaktadırlar. Lisansüstü mezunlar ilkokul mezunlarına göre daha çok içinde sağlığa zararlı madde bulunan ürünü influencerlar tavsiye etse de kullanmamaktadırlar. Lise mezunları ilkokul mezunlarına göre daha çok çoğu zaman influencerların tercihlerinin değişmesinde etkili olduğunu düşünmektedirler.

Tablo 10. Gelir ve İfadeler Arasındaki Anlamlı Farklar

\begin{tabular}{|c|c|c|c|c|c|c|}
\hline İFADELER & GELİR & $\begin{array}{l}\text { Sum of } \\
\text { Squares }\end{array}$ & df & $\begin{array}{c}\text { Mean } \\
\text { Square }\end{array}$ & $\mathbf{F}$ & Sig. \\
\hline \multirow{2}{*}{$\begin{array}{l}\text { Takipçisi çok olan } \\
\text { influencerın } \\
\text { tavsiyelerine her zaman } \\
\text { güvenirim. }\end{array}$} & Between Groups & 19.694 & 3 & 6.565 & \multirow{2}{*}{4.802} & \multirow{2}{*}{.003} \\
\hline & Within Groups & 678.098 & 496 & 1.367 & & \\
\hline \multirow[t]{2}{*}{$\begin{array}{l}\text { Influencerları samimi } \\
\text { buluyorum }\end{array}$} & Between Groups & 10.902 & 3 & 3.634 & \multirow{2}{*}{3.231} & \multirow[t]{2}{*}{.022} \\
\hline & Within Groups & 557.890 & 496 & 1.125 & & \\
\hline \multirow{2}{*}{$\begin{array}{l}\text { Influencerların } \\
\text { yaptıkları çekilişlerin } \\
\text { doğru olduğunu } \\
\text { düşünmüyorum. } \\
\end{array}$} & Between Groups & 21.025 & 3 & 7.008 & \multirow{2}{*}{4.472} & \multirow{2}{*}{.004} \\
\hline & Within Groups & 777.303 & 496 & 1.567 & & \\
\hline
\end{tabular}




\begin{tabular}{|l|c|c|c|c|c|c|}
\hline $\begin{array}{l}\text { Ürüne ihtiyacım olmasa } \\
\text { da influencerın anlatımı } \\
\text { sonrası satın alırım. }\end{array}$ & Between Groups & 13.613 & 3 & 4.538 & \multirow{2}{*}{3.790} & \multirow{2}{*}{.010} \\
\cline { 2 - 5 } & Within Groups & 593.875 & 496 & 1.197 & \\
\hline
\end{tabular}

Tablo 10'da gelir değişkeni ile ifadeler arasındaki anlamlı farklar yer almaktadır. Geliri 40016000 TL arasında olan katılımcılar geliri 6001 TL olan katılımcılara göre daha çok takipçisi çok olan influencerların tavsiyelerine her zaman güvenmektedirler. Geliri 2325 TL ve altında olanlar 2326-4000 TL arasında geliri olanlara göre daha çok influencerları samimi bulmaktadırlar. $2325 \mathrm{TL}$ ve altında geliri olanlar 2326-4000 TL arasında geliri olanlara göre daha çok influencerların yaptıkları çekilişlerin doğru olduğunu düşünmemektedirler. 4001 6000 TL arası geliri olanlar 2325 TL ve altında geliri olanlara göre daha çok ürüne ihtiyacı olmasa da influencerların anlatımı sonrası ürünü satın aldıklarını ifade etmişlerdir.

\section{SONUÇ ve ÖNERILER}

Pazarlamanın olmazsa olmazı tüketicilerdir. Tüketiciler sergiledikleri davranışlar ile gerek işletmeler gerekse genel olarak ekonomide belirleyici bireylerdir. Tüketici davranışlarına yön veren çeşitli kişi ve etkenler söz konusudur. Tüketicilerin davranışlarında; aile, arkadaş çevresi, toplum en bilinen etkileyicilerdir.

Günümüzde teknolojinin hızla artışı, sosyal medya platformlarındaki çeşitlilik, tüketicilerin farklı türdeki istekleri fikir liderlerini daha ön plana çıkarmıştır. Sözü edilen bu kavramlardan dolayı influencerlar son yıllarda tüketici için bir fikir lideri olmuş durumdadır.

Çalışmada influencerların tüketiciler tarafından bir fikir lideri olarak görülüp görülmediği araştırılmış ve farklı demografik özelliklerine göre tüketicilerin influencerları bir fikir lideri olarak gördüğü sonucuna ulaşılmıştır.

Çalışmada tüketicilerin cinsiyet, eğitim, yaş ve gelir durumlarına göre anlamlı sonuçlara ulaşılmıştır. Tüketiciler en çok kişisel bakım ve giyim alanındaki influencerları takip etmektedirler.

Kadın tüketiciler en çok temizlik, kişisel bakım ve giyim alanındaki influencerları takip etmektedirler. Erkek tüketicilerin takip ettikleri ise; otomotiv ve teknoloji alanındaki influencerlardır. Erkek tüketicilerin influencerların yanlış yönlendirmelerinde kadın tüketicilere göre daha sert tepki verdikleri araştırmanın bir başka sonucudur. Erkek tüketiciler influencerı takibi bırakabilirken, kadın tüketiciler bu kadar kesin tepki vermemektedirler.

Çalışmanın bir başka sonucu da yaş arttıkça influencerları takibin azalması, yaş azaldıkça da takibin artması olmuştur. Genç nüfus teknolojiyi daha iyi kullanabildiğinden yaş ve takip ters orantılı olarak karşımıza çıkmaktadır. Genç nüfus sadece yurt içindeki değil yurt dışındaki influencerları da takip etmekte ve eğer yanlış yönlendirilirlerse daha yaşlı tüketicilere göre daha sert tepkiler verebilmektedirler.

Genelde tüketiciler 2 ile 4 arasında influencer takip etmektedirler. Eğitim düzeyi arttıkça takip edilen influencerın artması araştırmada elde edilen bir başka sonuçtur. Eğitim düzeyi daha yüksek olan tüketiciler gerek zaman tasarrufu gerekse daha araştırıcı olma açısından influencerları takip etmektedirler. Eğitim düzeyi azaldıkça influencerların daha çok fikir lideri olarak görüldüğü sonucuna ulaşılmıştır. 
Gelir durumuna göre ise araştırmanın yapıldığı döneme ait asgari ücret ve altında gelir elde eden kesim daha çok takipte bulunmaktadır. $\mathrm{Bu}$ kesimi öğrencilerin oluşturduğu düşünüldüğünde yaş ve gelir değişkenleri elde edilen sonucu doğrular niteliktedir. Gelir düzeyi azaldıkça influencerların daha çok fikir lideri olarak görüldüğü sonucuna ulaşılmıştır. Gelir düzeyi yüksek olanların da takipçi sayısı fazla olan influencerlara daha çok güvendiği sonucuna ulaşılmıştır.

Elde edilen sonuçlara göre gelecek yıllarda influencerların öneminin daha da artacağ1 görülmektedir. Çalışma sonucunda, influencerlara eğer tüketicilerin gözünde bir fikir lideri olarak kendilerini görmek istiyorlarsa; tüketicileri yanıltmamaya özen göstermeleri önerilmektedir. İşletmeler açısından da ürünlerini tanıtıp tutundurma anlamında influencerlarla işbirliğinde bulunmaları tavsiye edilmektedir.

Daha sonra yapılacak çalışmalarda, araştırmacılara nitel yöntemlerle desteklenen, farklı kültürel yapıdaki tüketicilerin davranışlarını araştırmaları önerilmektedir.

\section{KAYNAKÇA}

AUF, M. A. A., MEDDOUR, H., SAOUlA, O., and MAJiD, A. H. A. (2018). "Consumer Buying Behaviour: The Roles Of Price, Motivation, Perceived Culture İmportance, And Religious Orientation". Journal of Business and Retail Management Research (JBRMR), 12(4): 177-186.

BROWN, D. ve HAYES, N. (2008). Influencer Marketing, Elsevier, Hungary.

CANÖZ, K., GÜLMEZ, Ö. ve EROĞLU, G. (2020). "Pazarlamanın Yükselen Yıldızı Influencer Marketing: Influencer Takipçilerinin Satın Alma Davranışını Belirlemeye Yönelik Bir Araştırma”. Selçuk Üniversitesi Sosyal Bilimler Meslek Yüksekokulu Dergisi, 23 (1): 73-91.

CONSTANTINIDES, E. (2004). “Influencing The Online Consumer's Behavior: The Web Experience". Internet Research, 14(2): 111-126.

DENIZ, R. B: (2020). Instagramda Pazarlama Stratejileri ve Uygulamalarına Yönelik Bir İrdeleme, International European Journal of Managerial Research Dergisi , 4(7): 150167.

GEDIK, Y. (2020). Sosyal Medyada Yükselen Bir Trend: Influencer Pazarlama Üzerine Kavramsal Bir Değerlendirme, Pamukkale Üniversitesi İşletme Araştırmaları Dergisi, 7(2): 362-385.

GÜLTEKİN, B. (2005). "Fikir Liderlerinin Halkla İlişkiler Amaçlı Kullanılması Hacı Bektaş Veli". Türk Kültürü ve Haci Bektaş Veli-Araştırma Dergisi , 34: 211-228.

HACIEFENDİOĞLU, Ş. (2011). "Reklam Ortamı Olarak Sosyal Paylaşım Siteleri ve Bir Araştırma”. Bilgi Ekonomisi ve Yönetimi Dergisi, 6(1): 107-115.

https://www.webtekno.com/influencer-ne-demek-h91000.html. Erişim tarihi: 10.01.2021.

İSLAMOĞLU, A. H. (2003). Tüketici Davranışları, Beta, İstanbul,

İSLAMOĞLU, A. H., ve Altunışık, R. (2008). Tüketici Davranışları, Beta, 2.baskı, İstanbul.

JAHNKE, M. (2018). Influencer Marketing, Springer Gabler, Hamburg. 
KHAN, M. (2006). Consumer Behaviour and Advertising Management, New Age Publishers, New Delhi.

KÖYLÜOĞLU, A. S., İNAN, Ü. S. E., and ACAR, Ö. E. (2018). "A Research on Consumer Behaviour: Konya Sample." China-USA Business Review, 17(6): 316-323.

LAKSHMI, S. (2016). "Consumer Buyıng Behavıor Towards Onlıne Shoppıng”. International Journal of Research - Granthaalayah, 4: 60-65.

NUNES, R. H., FERREIRA, J. B., FREITAS, A. S., RAMOS, F. L. (2018). "The Effects of Social Media Opinion Leaders' Recommendations on Followers' Intention to Buy". Revista Brasıleıra De Gestão De Negócıos Review of Busıness Management, 20(1): 57-73.

ODABAŞI, Y., ve BARIŞ, G., (2007). Tüketici Davranışı, 7.baskı, MediaCat, İstanbul.

ÖZDEMIR, S. S., ÖZDEMIR, M., POLAT, E., ve AKSOY, R. (2014). "Sosyal Medya Kavramı ve Sosyal Ă̆ Sitelerinde Yer Alan Onlıne Reklam Uygulamalarının İncelenmesi". Electronic Journal of Vocational Colleges, 4(4): 58-64.

ÖZDEMİ, Ş., KARACA, Y., SANDIKÇI, M, YAMAN, F., ve AVAN, A. (2016). Afyonkarahisar İli Hane Halkı Tüketim Analizi, Tüketici Davranışları ve Eğilimleri, Ekin Kitabevi, Ankara.

PEİGHAMBARİ, K., SATTARİ, S., KORDESTANI, A., and OGHAZİ, P. (2016). "Consumer Behavior Research: A Synthesis of the Recent Literature". SAGE Open, 6(2): $1-9$.

SARITAŞ, A. (2018). Sosyal Medya Reklamlarında Fenomen Kullanımı ve Reklam İzleme Tercihi, The Journal of International Scientific Researches, 3(4): 62-74.

ŞİMŞEK, G. (2013). “Kişisel Mecralarda Reklam Yayını: Kişilerin Sosyal Medyada Reklam Paylaşım Motivasyonları”. Akademik İncelemeler Dergisi (Journal of Academic Inquiries) 8(3): 213-239.

TEJAVİBULYA, P., ve EİAMKANCHANALAİ, S. (2011). "The Impacts of Opinion Leaders towards Purchase Decision Engineering under Different Types of Product Involvement". Systems Engineering Procedia, 2: 12 - 22

TREPTE, S., SCHERER, H. (2010). “Opinion Leaders - Do They Know More Than Others About Their Area Of Interest?”. Communications, 35: 119-140. 